\title{
Physiological effects of land and water treadmill exercise in dogs
}

\author{
Mayara Marques Pereira Fernandes ${ }^{1 *}$ Ana Caroline Lima da $\mathbf{C r u z}^{2}$ (우

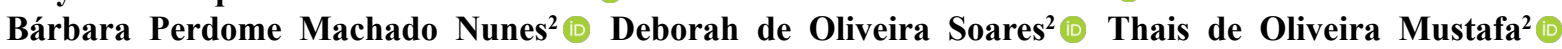 \\ Patricia Santos Ferreira Peruquetti ${ }^{1}\left[\right.$ Patrícia Fernandes Nunes da Silva Malavazi ${ }^{3}[$ \\ Acácio Duarte Pacheco ${ }^{3}$ (1) Soraia Figueiredo de Souza $^{3}$ (i)
}

\begin{abstract}
'Programa de Pós-Graduação em Sanidade e Produção Animal Sustentável na Amazônia Ocidental, Universidade Federal do Acre (UFAC), Rio Branco, AC, Brasil. CEP: 69915-900. E-mail: mpf.mayara@gmail.com. .Corresponding author.

${ }^{2}$ Graduação em Medicina Veterinária, Universidade Federal do Acre, (UFAC), Rio Branco, AC, Brasil.

${ }^{3}$ Centro de Ciências Biológicas e da Natureza, Universidade Federal do Acre (UFAC), Rio Branco, AC, Brasil.

ABSTRACT: The application of hydrotherapy is growing in the field of animal rehabilitation to improve strength, endurance, fitness, and range of motion, in addition to reducing pain. In the same way, land-based activity is recommended for various conditions, including hypertension, muscle atrophy, and obesity. There is a lack of studies that evaluate the safety of incremental exercise in American Pit Bull Terriers. This study assessed the influence of activity on underwater and dry land treadmills on the physiological parameters of dogs. In this regard, 12 adult, male, healthy, and untrained American Pit Bull Terriers were subjected to an incremental exercise test (IET) on the underwater treadmill (Group I) and the dry land treadmill (Group II). Heart rate (HR), respiratory rate (RR), rectal temperature (RT), systolic blood pressure (SBP), and electrocardiographic evaluation, were evaluated before activity (T0), immediately after (T1), 30 min after (T2), and 90 min after the end of exercise (T3), and plasmatic lactate concentrations were measured at T0, T1, and T2 time points. Results obtained were submitted to the Shapiro-Wilk test, ANOVA and Tukey's test, considering $P<0.05$. Water activity induced a reduction in $R R(P=0.00674)$ in all examinations after the test on the underwater treadmill and proved to be more demanding than activity on the land treadmill, considering the presence of a deeper and slower RR. Exercise sessions in both groups did not elevate the lactate concentration. The IET can be performed safely on an underwater or dry land treadmill in healthy American Pit Bulls.
\end{abstract}

Key words: electrocardiography, physiology, underwater treadmill, animal rehabilitation, incremental exercise test, American Pit Bull Terrier.

Efeitos do exercício em esteira terrestre ou aquática sobre os parâmetros fisiológicos de cães

RESUMO: A hidroterapia apresenta crescente aplicação no ramo da reabilitação animal, com o intuito de aumentar a força, resistência muscular e amplitude de movimento articular, além de reduzir a dor e melhorar o condicionamento físico do paciente. Assim como a hidroterapia, a atividade desenvolvida em solo é indicada para diversas afecções, inclusive para pacientes hipertensos, com atrofia muscular ou com sobrepeso. São escassos os estudos que avaliam a segurança de testes incrementais em esteira aquática e em esteira seca em American Pit Bull Terriers. Este estudo teve como objetivo avaliar os efeitos da atividade em esteira aquática e em esteira seca sobre os parâmetros fisiológicos de cães. Para isto, cães da raça American Pit Bull Terrier (n=12) machos, adultos, saudáveis e não treinados foram submetidos a teste de esforço incremental (TEI) em hidroesteira com água (Grupo I) e sem água (Grupo II). A frequência cardíaca (FR), frequência respiratória (FR), temperatura retal (TR), pressão arterial sistólica (PAS) e avaliação eletrocardiográfica, foram aferidas antes da atividade (T0), imediatamente após (T1), 30 minutos após (T2) e 90 minutos após o exercício (T3), e a concentração plasmática de lactato foi dosada nos momentos TO, TI e T2. Os resultados foram submetidos ao teste de Shapiro-Wilk, análise de variância (ANOVA) e pelo Teste de Tukey, considerando significativo o valor de $P<0.05$. Houve diminuição da frequência respiratória $(P=0,00674)$ após a atividade em esteira aquática, que se mostrou mais exigente que a atividade em esteira terrestre, considerando a apresentação de padrão respiratório mais lento e profundo. As sessões de exercício em ambos os grupos não elevaram a concentração de lactato. $O$ teste de esforço incremental em esteira aquática, ou em esteira seca, pode ser desenvolvido com segurança por cães American Pit Bull saudáveis.

Palavras-chave: eletrocardiografia, fisiologia, hidroesteira, reabilitação animal, teste de esforço incremental, American Pit Bull Terrier.

\section{INTRODUCTION}

Activity on an underwater treadmill presents several indications for dogs, such as an increase in muscle mass and an improvement in the quality of life of overweight or cardiopathic animals (XAVIER et al., 2018). In contrast, land-based activity is often indicated to improve cardiorespiratory fitness and prevent loss of lean body mass, especially for overweight or hypertensive patients, resistance training, 
and sports performance improvement (VITGER et al., 2016; NGOMANE et al., 2018). However, the ideal training load to be applied in the canine species remains unknown once most of the workload applied in training protocols is determined by the response of the animals (PELLEGRINO et al., 2014; IMPELLIZZERI et al., 2018; OROZCO et al., 2021).

To provide a higher energy demand in vigorous exercise, muscles begin to obtain energy anaerobically, causing the release of substances, such as lactate, into circulation (WAKSHLAG, 2018). Thus, measuring lactate concentration is an important tool to adjust exercise protocols to improve physical performance of individuals (PELLEGRINO et al., 2014; RESTAN et al., 2019).

Several controlled clinical studies using healthy dogs to evaluate the results, efficacy, and safety of various conditioning modalities are necessary (RESTAN et al., 2019). Berkman (2015) evaluated the physiological parameters of American Pit Bull Terriers submitted to the incremental exercise test (IET) on a dry land treadmill, but studies performed on an underwater treadmill for dogs could be considered a gap in the literature. This study tested the hypothesis that the IET performed on underwater and dry land treadmills can cause different effects on the physiological parameters of American Pit Bull Terriers. We also attempted to contribute to forming safer and more effective therapeutic protocols to benefit various canine species, especially American Pit Bull Terriers.

\section{MATERIALS AND METHODS}

This study was developed at the Unidade de Ensino e Pesquisa em Medicina Veterinária, Universidade Federal do Acre (UFAC), and evaluated 12 domiciled American Pit Bull Terrier dogs (Canis familiaris). All animals were healthy adult males, untrained, and had ideal body scores according to Laflamme (1997).

\section{Exercise sessions}

The animals were submitted to two adaptation sessions before IET. During the first adaptation session, the animals were placed on an elevated and disconnected treadmill and received positive reinforcement (snacks, affection) (CERQUEIRA et al., 2018; RESTAN et al., 2019). The treadmill was lowered slowly and gradually and was started at $0.31 \mathrm{mph}$, with gradual speed increments. The sessions were finished when the animals showed signs of fatigue or reluctance to perform the exercise.
After a minimum interval of $48 \mathrm{~h}$, the second adaptation session was performed in the same way as the previous one but on a dry land treadmill.

Physical activity was developed on a treadmill coupled to a polycarbonate tank, with a $0 \%$ slope. During the experimental period, all animals were subjected to IET on the underwater treadmill (Group I) and the dry land treadmill (Group II), obeying the minimum interval of $48 \mathrm{~h}$ between sessions so as not to impair the performance of the animals in each modality (BELFORT et al., 2018). For Group I, the water for the treadmill was heated to $32^{\circ} \mathrm{C}$ (NGOMANE et al., 2018), and the depth was at the level of the greater trochanter of the femur (BELFORT et al., 2018) (Figure 1).

Half of the animals $(n=6)$ started the incremental test with the underwater treadmill modality, whereas the other half performed the test in reverse order to reduce the bias of the experiment. The IET protocol consisted of a 2-min warm-up period at $0.62 \mathrm{mph}$, followed by increments of 0.31 mph every $2 \mathrm{~min}$. The test was completed when the dogs began to show signs of fatigue or anxiety (CERQUEIRA et al., 2018; RESTAN et al., 2019). The animals were then kept at rest to avoid changes in subsequent evaluations.

\section{Physical examination}

Physical examination was performed at four time points: before the ITE (T0), immediately after (T1), 30 min after (T2), and 90 min after (T3) exercise, and thus each animal acted as its control (BELFORT et al., 2018; XAVIER et al., 2018). It consisted of measuring heart rate (HR), respiratory rate $(\mathrm{RR})$, rectal temperature (RT), systolic blood pressure (SBP), and electrocardiographic evaluation.

The ECG examination was performed by digital electrocardiography, with the animal positioned in the right lateral decubitus position (SOUSA et al., 2018). This examination was recorded for $7 \mathrm{~min}$ and traced derivation II (DII) for the subsequent analysis of the amplitude $(\mathrm{mV})$ of the $\mathrm{P}$ wave and the R wave, and the duration ( $\mathrm{ms}$ ) of the $\mathrm{P}$ wave, the QRS complex, and the QT and PR intervals. The analyses were performed by a professional who did not know the treatments to promote impartial data analysis (MENEGHETI et al., 2014).

The SBP (mmHg) was measured using Portable Vascular Doppler (Parks Medical - Model 811-B). Due to the dogs' physical conformation, which has a large musculature, SBP was measured from the medial sacral artery (coccygeal), with a cuff that was appropriately sized for the circumference of the tail (HABERMAN et al., 2006). 


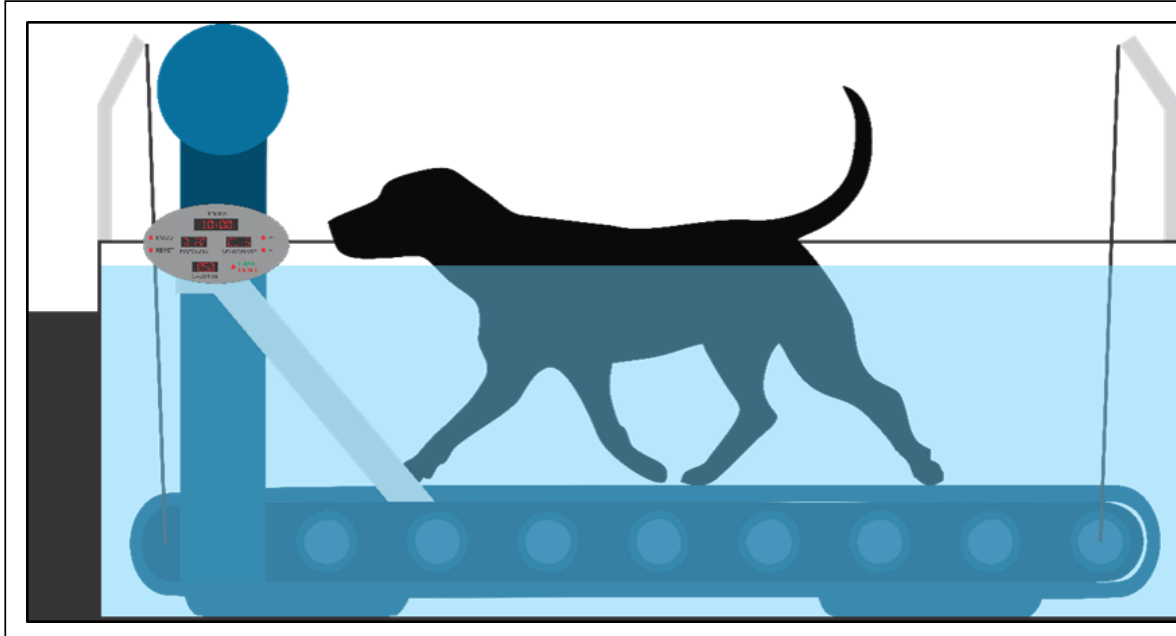

Figure 1 - Representative scheme of underwater treadmill to perform physical tests. Water level at the greater trochanter height.

\section{Blood collection}

Plasma lactate was measured before the beginning of the IET (T0), immediately after (T1), and $30 \mathrm{~min}$ after the test (T2). Blood samples were collected from the cephalic vein of the dogs and packed in sodium fluoride tubes.

The samples were sent to the Laboratory of Clinical Analysis and Parasitology of the institution and centrifuged at $3000 \mathrm{rpm}$ for $5 \mathrm{~min}$ to obtain the plasma, which was aliquoted and stored in cryotubes at $-20{ }^{\circ} \mathrm{C}$. Lactate was determined by the colorimetric enzymatic method on a semi-automatic biochemical analyzer (Bioplus - BIO-200), using the enzymatic lactate kit (Labtest), according to the instructions of the laboratory.

\section{Statistical analysis}

Results obtained were tabulated and submitted to the Shapiro-Wilk normality test. The electrocardiographic parameters were analyzed using analysis of variance (ANOVA). The other variables were analyzed by an ANOVA for repeated samples, followed by Tukey's test, considering $\mathrm{P}<0.05$ as statistically significant (BERKMAN et al., 2016). Data analyses were performed using STATISTICA (Data Analysis Software SystemStatSoft, Inc., Tulsa, USA), version 12.

\section{RESULTS AND DISCUSSION}

The 12 animals that participated in this experiment had an average age of $38( \pm 26.6)$ months and a mean weight of $37.0( \pm 6.0) \mathrm{kg}$. The mean ambient temperature was $24.3{ }^{\circ} \mathrm{C}\left( \pm 0.4{ }^{\circ} \mathrm{C}\right)$, and the estimated relative air humidity was $56.9 \%( \pm 5.2 \%)$.

In Group I, the RR was lower $(\mathrm{P}=0.00674)$ in all measurements after activity (i.e., at T1, T2, and T3). RR averages in Group II were higher than those in Group I at time points T1 and T2 (Figure 2). No differences were observed between Groups I and II regarding the other parameters evaluated (HR, RT, SBP, ECG, and lactate concentration) (Table 1).

In a previous study with mixed-breed dogs, Belfort et al. (2018) also observed a decrease in the RR averages after trekking and swimming in a swimming pool. However, it did not have a statistically significant difference, probably due to the small number of samples $(n=5)$ in each group.

In a study with Quarter horses, Greco-Otto et al. (2017) reported lower RR averages at the highest water level on the underwater treadmill, which the authors attributed to the increased workload and; consequently, to the higher energy expenditure required in response to a greater depth, inducing a slower and deeper breathing pattern. This type of breathing pattern favored alveolar ventilation and gas exchange.

These results corroborated the findings of this study, since the animals in Group I performed the IET with the water level at a depth of the great trochanter. Therefore, the decrease in respiratory movements is related to the demand for greater effort to perform the activity on a treadmill, considering that there was an increasing amount of resistance to movement due to the depth of water at each increment in speed during the test (LEVINE et al., 2014).

Ciência Rural, v.52, n.9, 2022. 


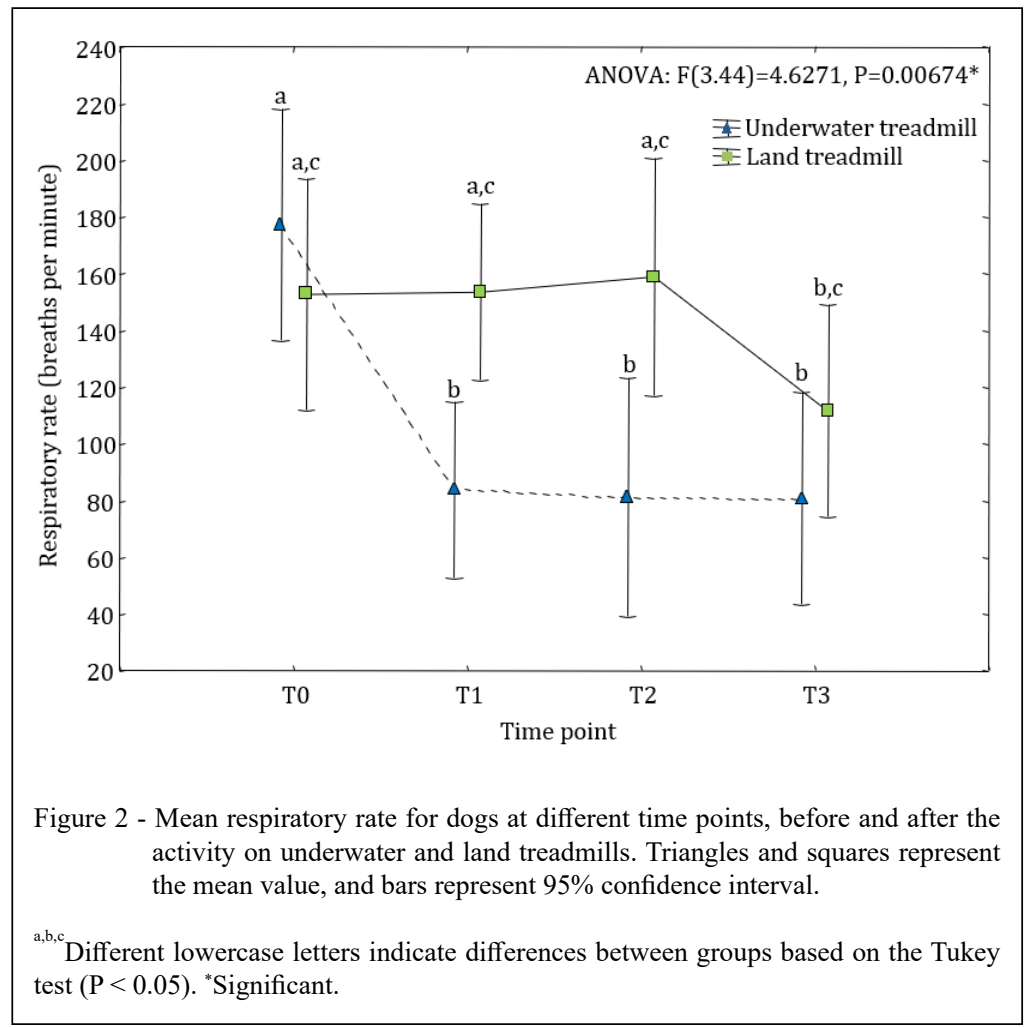

The maintenance of significantly lower RR averages in subsequent measurements of activity also reflects the relaxation promoted by activity in partial immersion, since the animals were calmer after activity on the underwater treadmill.

The activity on the underwater treadmill and the dry land treadmill did not cause significant alterations in the SBP of the animals. The literature describes the influence of activity in water to reduce blood pressure in humans and animals; however, such an effect is more effectively obtained by performing the activity at higher temperatures $\left(32-40{ }^{\circ} \mathrm{C}\right)$, due to peripheral vasodilation caused by heated water (LEVINE et al., 2014; NGANVONGPANIT et al., 2014; NGOMANE et al., 2018).

RT and HR averages were statistically similar in all measurements of both modalities, suggesting that the duration and/or intensity of the activity was not so vigorous as to provoke an expressive increase in metabolic rate, which could lead to higher heat production (KLEIN, 2014), or to cause a remarkable increase of the oxygen demand, which would induce the presentation of tachycardia (ROVIRA et al., 2010; PICCIONE et al., 2012; BERKMAN et al., 2016).
Regarding the ECG evaluations, there was no significant difference between the two groups. Similar results were described during agility training with German Shepherds and Belgian Shepherds of Malinois (ROVIRA et al., 2010) and search and rescue training with dogs of different breeds (SANTOS et al., 2018). Data indicate that there were no exercise-induced electrical and conductivity cardiac changes in dogs.

The lactate concentration did not differ between the two groups $(\mathrm{P}=0.5883)$ and did not exceed the concentration proposed by Mathews (2012), which admitted that normal plasma lactate concentration can reach values of approximately 3.5 $\mathrm{mmol} / \mathrm{L}$ in dogs.

As observed in this study, Swanson et al. (2019) also reported that walking and trotting on a treadmill for $30 \mathrm{~min}$ at a maximum speed of $3.97 \mathrm{mph}$ did not cause significant variations in the lactate concentrations of the dogs that performed the activity.

BERKMAN et al. (2016) reported that the Pit Bulls submitted to IET showed an abrupt and significant elevation of lactate concentration at a speed of $8.94 \mathrm{mph}$ on a dry land treadmill with $5 \%$ elevation. Restan et al. (2019), in turn, reported that 
Table 1 - Mean and standard deviation of physiological parameters and lactate concentration measured before the exercise (T0), immediately after (T1), 30 minutes after (T2), and 90 minutes after the exercise (T3) on the underwater treadmill (Group I) and dry land treadmill (Group II).

\begin{tabular}{|c|c|c|c|c|c|c|c|c|c|}
\hline \multirow{2}{*}{$\begin{array}{l}\text { Time } \\
\text { point }\end{array}$} & \multicolumn{4}{|c|}{-----------Underwater treadmill Mean ( $( \pm \mathrm{SD})----------$} & \multicolumn{4}{|c|}{----------Dry land treadmill Mean ( $( \pm \mathrm{SD})$-------- } & \multirow[t]{2}{*}{$\mathrm{P}$ value } \\
\hline & T0 & $\mathrm{T} 1$ & $\mathrm{~T} 2$ & $\mathrm{~T} 3$ & T0 & $\mathrm{T} 1$ & $\mathrm{~T} 2$ & $\mathrm{~T} 3$ & \\
\hline $\begin{array}{l}\text { FC } \\
(\mathrm{bpm})\end{array}$ & $\begin{array}{c}130.0 \\
( \pm 16.0)\end{array}$ & $\begin{array}{c}129.0 \\
( \pm 23.1)\end{array}$ & $\begin{array}{c}127.7 \\
( \pm 27.4)\end{array}$ & $\begin{array}{c}118.2 \\
( \pm 31.7)\end{array}$ & $\begin{array}{c}130.3 \\
( \pm 30.8)\end{array}$ & $\begin{array}{c}142.0 \\
( \pm 26.0)\end{array}$ & $\begin{array}{c}123.1 \\
( \pm 27.4)\end{array}$ & $\begin{array}{c}128.0 \\
( \pm 33.8)\end{array}$ & 0.2548 \\
\hline $\begin{array}{l}\text { FR } \\
\text { (mrpm) }\end{array}$ & $\begin{array}{c}177.3 \\
( \pm 59.3)\end{array}$ & $\begin{array}{c}83.8 \\
( \pm 54.9)\end{array}$ & $\begin{array}{c}81.3 \\
( \pm 64.9)\end{array}$ & $\begin{array}{c}80.7 \\
( \pm 59.6)\end{array}$ & $\begin{array}{c}152.8 \\
( \pm 75.9)\end{array}$ & $\begin{array}{c}153.7 \\
( \pm 48.6)\end{array}$ & $\begin{array}{c}159.0 \\
( \pm 75.2)\end{array}$ & $\begin{array}{c}111.7 \\
( \pm 65.7)\end{array}$ & $0.0067^{\prime}$ \\
\hline $\operatorname{TR}\left({ }^{\circ} \mathrm{C}\right)$ & $39.0( \pm 0.7)$ & $38.8( \pm 0.4)$ & $38.5( \pm 0.4)$ & $38.3( \pm 0.4)$ & $39.1( \pm 0.7)$ & $39.0( \pm 0.9)$ & $38.7( \pm 0.5)$ & $38.3( \pm 0.4)$ & 0.7469 \\
\hline $\begin{array}{l}\text { PAS } \\
(\mathrm{mmHg})\end{array}$ & $\begin{array}{l}129.7 \\
( \pm 6.8)\end{array}$ & $\begin{array}{l}127.3 \\
( \pm 9.3)\end{array}$ & $\begin{array}{c}123.6 \\
( \pm 11.7)\end{array}$ & $\begin{array}{c}124.4 \\
( \pm 15.2)\end{array}$ & $\begin{array}{c}132.9 \\
( \pm 13.0)\end{array}$ & $\begin{array}{c}132.0 \\
( \pm 8.9)\end{array}$ & $\begin{array}{c}127.4 \\
( \pm 12.0)\end{array}$ & $\begin{array}{c}123.3 \\
( \pm 13.6)\end{array}$ & 0.6562 \\
\hline $\begin{array}{l}\text { Lactate } \\
(\mathrm{mg} / \mathrm{dL})\end{array}$ & $\begin{array}{c}30.3 \\
( \pm 18.6)\end{array}$ & $\begin{array}{c}26.0 \\
( \pm 11.9)\end{array}$ & $\begin{array}{c}26.0 \\
( \pm 14.9)\end{array}$ & - & $\begin{array}{c}26.8 \\
( \pm 18.4)\end{array}$ & $\begin{array}{c}27.1 \\
( \pm 10.8)\end{array}$ & $\begin{array}{c}22.9 \\
( \pm 15.8)\end{array}$ & - & 0.5883 \\
\hline
\end{tabular}

${ }^{*} \mathrm{P}<0.05$

the Beagles reached the lactate threshold due to an increase on the dry land treadmill at $7.76 \mathrm{mph}$, with an incline of $7.5 \%$.

In this study, the average speed reached by the animals in Group I was $3.78( \pm 1.02) \mathrm{mph}$, and the test was completed with speeds of 2.17-5.28 mph. In Group II, the average reached was $3.37( \pm 0.97) \mathrm{mph}$, varying at the end of the test with speeds of 2.17-4.97 $\mathrm{mph}$. The time of activity was also similar between the two groups, $22 \mathrm{~min}$ on average on the underwater treadmill modality and 19 min on the dry land treadmill.

In this way, the intensity reached in this study by the dogs on underwater treadmill and dry land treadmill tests was characterized as light to moderate, according to the scale of effort perception for dogs suggested by Swanson et al. (2019).

Results indicated that the incremental tests did not cause muscular fatigue in healthy and untrained Pit Bulls, considering physiological parameters and plasmatic lactate concentrations. However, a potential limitation of this research was the use of lactate concentration as the main indicator of muscle fatigue, since this substance is present in a large part of mammalian metabolism, according to Brooks (2020). Therefore, this indicator should be combined with other parameters and biochemical markers to elucidate the effects provoked by physical activity in several systems (CERQUEIRA et al., 2018; TOSI et al., 2021).

It is also possible to infer that, although the tests were performed until the animals presented signs of fatigue and/or intolerance to exercise, the modalities remained characterized as aerobic activity. The activation of anaerobic glycolysis was unnecessary to supply energy to muscles since this would have been reflected as an abrupt elevation in lactate concentrations (RESTAN et al., 2019).

\section{CONCLUSION}

Activity on the underwater treadmill proved to be more demanding than exercise on the land treadmill, once the animals presented a slower and deeper breathing pattern in this modality. The workload applied in both modalities did not induce blood lactate elevation. American Pit Bull Terrier dogs demonstrated adequate physical conditioning from light to moderate exercise on underwater and land treadmills.

\section{ACKNOWLEDGEMENTS}

The authors are grateful to the Coordenação de Aperfeiçoamento de Pessoal de Nível Superior (CAPES), Brasil, Finance code 001.

\section{BIOETHICS AND BIOSSECURITY COMMITTEE APPROVAL}

This study was developed with approval by the institutional Ethics Committee on the Use of Animals (CEUA/ UFAC), under the protocol $n^{\circ} 05 / 2019$.

\section{DECLARATION OF CONFLICT OF INTEREST}

The authors have no competing interests. 


\section{AUTHORS' CONTRIBUTIONS}

All authors contributed to the manuscript.

\section{REFERENCES}

BELFORT, A. S. et al. Avaliação clínica e bioquímica de cães submetidos a dois métodos de hidroterapia. Arq. Bras. Med. Vet. Zootec, v.70, n.6, p.1736-1746, 2018. Available from: <http:// dx.doi.org/10.1590/1678-4162-9983>. Accessed: Mar. 12, 2019. doi: $10.1590 / 1678-4162-9983$.

BERKMAN, C. Cães American Pit Bull Terrier submetidos a exercício: Respostas Fisiológicas e Estudo Comparativo de métodos para quantificação de lactato. 2015. 58f. Tese em Medicina Veterinária. Programa de Pós Graduação em Clínica Médica Veterinária da Faculdade de Ciências Agrárias e Veterinárias da Universidade Estadual Paulista - Campus de Jaboticabal. Available from: <https://repositorio.unesp.br/ bitstream/handle/11449/128001/000848501.pdf;jsessionid=499 569519862203F988132D2EE7E1D75? sequence=1>. Accessed: Jul. 20, 2021

BERKMAN, C. et al. Agreement between i-STAT and YSI 2300 devices to determine lactate concentrations in dogs undergoing exercise. Comp. Exerc. Physiol, v.12, n.2, p.75-82, 2016. Available from: <http://dx.doi.org/10.3920/ CEP160002>. Accessed: Mar. 12, 2019. doi: 10.3920/ CEP160002.

BROOKS, G. A. Lactate as a fulcrum of metabolism. Redox Biology, v.35, p.1-12, 2020. Available from: <https://doi. org/10.1016/j.redox.2020.101454>. Accessed: Aug. 19, 2020. doi: 10.1016/j.redox.2020.101454.

CERQUEIRA, J. et al. Intense exercise and endurance-training program influence serum kinetics of muscle and cardiac biomarkers in dogs. Res. Vet. Sci., v.121, n.1, p.31-39, 2018. Available from: $<$ https://doi.org/10.1016/j.rvsc.2018.10.004>. Accessed: Mar. 12, 2019. doi: 10.1016/j.rvsc.2018.10.004.

GRECO-OTTO, P. et al. Workload of horses on a water treadmill: effect of speed and water height on oxygen consumption and cardiorespiratory parameters. BMC Vet. Res., v.13, n.360, p.19, 2017. Available from: <https://doi.org/10.1186/s12917-0171290-2>. Accessed: Apr. 8, 2019. doi: 10.1186/s12917-017$1290-2$.

HABERMAN, C. et al. Evaluation of oscillometric and doppler ultrasonic methods of indirect blood pressure estimations on conscious dogs. Can. J. Vet. Res., v.70, n.3, p.211-217, 2006. Available from: <https://pubmed.ncbi.nlm.nih.gov/16850944/>. Accessed: Jun. 3, 2019.

IMPELLIZZERI, F. et al. Internal and External Training Load: 15 Years On. International Journal of Sports Physiology and Performance, v.14, n.2, p.270-273, 2018. Available from: <https:// doi.org/10.1123/ijspp.2018-0935>. Accessed: Aug. 17, 2021. doi: 10.1123/ijspp.2018-0935.

KLEIN, B. G. Cunningham Tratado de Fisiologia Veterinária 5.ed. Rio de Janeiro: Elsevier, 2014. 624p.

LAFLAMME, D. P. Development and validation of a body condition score system for dogs. Canine Pract., v.22, n.3, p.10-15,
1997. Available from: <https://agris.fao.org/agris-search/search. do?recordID=US9742264>. Accessed: Jul. 20, 2019.

LEVINE, D. et al. Aquatic therapy. In: MILLIS, D.L.; LEVINE, D. Canine Rehabilitation and Physical Therapy. 2.ed. St. Louis: Saunders, 2014. Cap.31, p.526-541.

MATHEWS, K. A. Monitoring fluid therapy and complications of fluid therapy. In: DIBARTOLA, S.P. Fluid, Electrolyte, and Acid-Base Disorders in Small Animal Practice. 4.ed. St. Louis: Saunders, 2012. Cap.16, p.386-404.

MENEGHETI, T. M. et al. Electrocardiographic evaluation of the degree of sedation and the isolated use of methadone in healthy dogs. Vet. Anaesth. Analg., v.41, n.1, p.97-104, 2014. Available from: <https://doi.org/10.1111/vaa.12086>. Accessed: Sep. 05, 2020. doi: 10.1111/vaa.12086.

NGANVONGPANIT, K. et al. Physiological Effects of Water Temperatures in Swimming Toy Breed Dogs. Kafkas Univ. Vet. Fak. Derg., v.20, n.2, p.177-183, 2014. Available from: $<$ https:// doi.org/10.9775/kvfd.2013.9710>. Accessed: Oct. 13, 2020. doi: 10.9775/kvfd.2013.9710.

NGOMANE A. et al. Effects of heated water-based exercise on blood pressure: a systematic review. Fisioter. Mov., v.31, p.1-16, 2018. Available from: <https://doi.org/10.1590/1980-5918.031.ao05>. Accessed: Oct. 23, 2020. doi: 10.1590/1980-5918.031.ao05.

OROZCO, S. et al. Efficacy of high-intensity interval training compared with moderate-intensity continuous training on maximal aerobic potency in dogs: Trial protocol for a randomised controlled clinical study. Veterinary Record Open, v.8, n.1, p.1-8, 2021. Available from: $<$ https://doi.org/10.1002/vro2.4>. Accessed: Aug. 18, 2021. doi: 10.1002/vro2.4.

PELLEGRINO, F. J. et al. Optimización del rendimiento deportivo en caninos. Rev. Inv. Vet. Perú, v.25, n.4, p.449-454, 2014. Available from: <http://dx.doi.org/10.15381/rivep.v25i4.10778>. Accessed: Nov. 05, 2019. doi: 10.15381/rivep.v25i4.10778.

PICCIONE, G. et al. Effect of moderate treadmill exercise on some physiological parameters in untrained beagle dogs. Exp. Anim., v.61, n.5, p.511-515, 2012. Available from: <https://doi. org/10.1538/expanim.61.511>. Accessed: Sep. 12, 2020. doi: 10.1538/expanim.61.511.

RESTAN, A. Z. et al. Lactate and glucose thresholds and heart rate deflection points for Beagles during intense exercise. Am. J. Vet. Res., v.80, n.3, p.284-293, 2019. Available from: <https://doi. org/10.1371/journal.pone.0233264>. Accessed: Jan. 06, 2020. doi: 10.1371/journal.pone.0233264.

ROVIRA, S. et al. Heart rate, electrocardiographic parameters and arrhythmias during agility exercises in trained dogs. Revue de Médecine Vétérinaire, v.161, n.7, p.307-313, 2010. Available from: $<\mathrm{https://www.}$ revmedvet.com/2010/RMV161_307 313.pdf>. Accessed: Jul. 20, 2020.

SANTOS, P. O. et al. Effect of exercise on cardiovascular parameters in search and rescue-trained dogs. Arq. Bras. Med. Vet. Zootec., v.70, n.4, p.1036-1044, 2018. Available from: $<$ https://doi.org/10.1590/1678-4162-10027>. Accessed: Jan. 06, 2020. doi:10.1590/1678-4162-10027.

SOUSA, M. G. et al. Influence of body position on the measurement of electrocardiographic waves in healthy dogs. Pesq. 
Vet. Bras., v.38, n.2, p.340-344, 2018. Available from: <https:// doi.org/10.1590/1678-5150-PVB-5071>. Accessed: Mar. 10, 2020. doi: 10.1590/1678-5150-PVB-5071.

SWANSON, K. D. et al. Development of a perceived exertion scale for dogs using selected physiologic parameters. J. Small Anim. Pract. v.60, n.4, p.247-253, 2019. Available from: <https://doi.org/10.1111/ jsap.12978>. Accessed: Feb. 08, 2020. doi: 10.1111/jsap.12978.

TOSI, I. et al. Acylcarnitine profile in Alaskan sled dogs during submaximal multiday exercise points out metabolic flexibility and liver role in energy metabolism. Plos One, v.16, n.8, p.1-19, 2021. Available from: $<$ https://doi.org/10.1371/journal.pone.0256009>. Accessed: Aug. 19, 2021. doi: 10.1371/journal.pone.0256009.
VITGER, A. D. et al. Integration of a physical training program in a weight loss plan for overweight pet dogs. J. Am. Vet. Med. Assoc., v.248, n.2, p.174-182, 2016. Available from: <https://doi.org/10.2460/ javma.248.2.174>. Accessed: Jul. 20, 2021. doi: 10.2460/javma.248.2.174.

WAKSHLAG, J. The role of nutrition in canine performance and rehabilitation. In: ZINK, C.; VAN DYKE, J.B. Canine Sports Medicine and Rehabilitation. 2.ed. Oxford: Wiley Blackwell, 2018. Cap.4, p.72-95.

XAVIER, J. S. et al. Efeito de diferentes intensidades de exercício em esteira sobre os parâmetros eletrocardiográficos de cães hígidos. Arq Bras. Med. Vet. Zootec., v.70, n.4, p.1080-1088, 2018. Available from: <http://dx.doi.org/10.1590/1678-41629310>. Accessed: Jan. 07, 2020. doi: 10.1590/1678-4162-9310. 